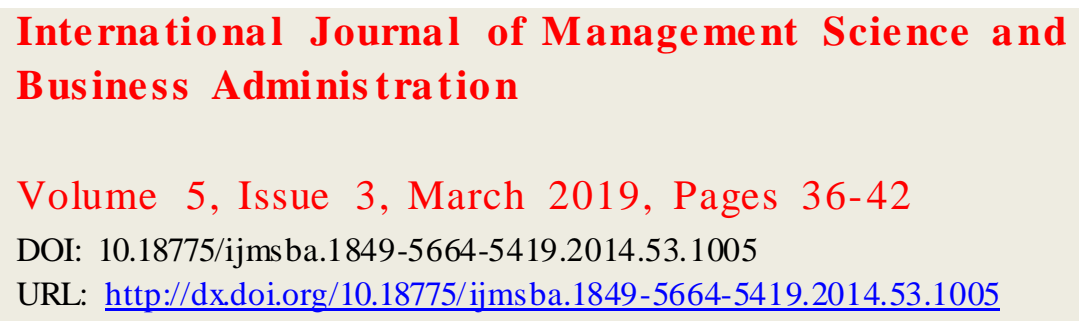

\title{
Pre-Primary Education: Its Impact on Academic Achievement of the Learners Learning at an Elementary Stage in Odia Language Subject in Odisha
}

\author{
${ }^{1}$ Rasmi Ranjan Puhan, ${ }^{2}$ Swagatika Ray, ${ }^{3}$ Sunakar Das \\ 1,2,3 Assistant Professor in Education, Rajdhani Govt. College Bhubaneswar, Odisha
}

\begin{abstract}
This paper discussed the impact of Pre-Primary Education on the academic achievement of the learners learning at an elementary stage in Odia language subject. The study dealt with the Descriptive Survey method in order to study the problem. The sample of 120 elementary learners of the class consisted of 60 boys and 60 girls using random sampling technique for this study. The investigator prepared a tool of Achievement test questionnaire with the help of the investigator and experts. The test questionnaire was prepared on Odia language subject for Class-I. This test measured the performance of the learners with and without Pre-Primary education in Odia Language subject. For the present study, the investigator used statistical techniques such as mean, standard deviation and t-test in order to compare the academic achievement of the learners. The findings of the study revealed that the learners learning in elementary level receiving Pre-Primary Education do better in their oral and written test in Odia Language subject than the learners receiving no Pre-Primary Education. There exists a significant difference between the performance of boys learning at elementary school level in Odia language subject both written and oral test with and without receiving pre-primary education. There exists a significant difference between the achievement of girls learning at elementary school level in Odia language subject both written and oral test with and without pre-primary education.
\end{abstract}

Keywords: Pre-Primary education, Academic achievement, Elementary stage, Odia language subject

\section{Introduction}

Education is a lifelong process which starts from the mother's womb and continues till tomb. It helps the individual to develop his all potentialities by controlling the environment for his own successful life and living. Education starts its foundation from ones very early childhood on which whole structure of educational progress in all spheres of life is shaped. This early childhood education and care are called pre-primary education. It starts at the age of three and ends at the age of six. As per the Indian Education Commission (1964-1966) early childhood education stimulates the starting of intellectual curiosity concerning the environment and to help them understanding the planet in which they live in and to foster new interest by providing opportunities to explore, investigate, experiment, with a view to promote physical, mental, social and aesthetic development of children. The pre-primary education occupies a pioneering role in the field of education. The modern trend in Educational policy is formed to emphasize pre-primary education, especially for children for the age group from 3 years to 6 years in order to make integral development of little children. Early childhood is a state of wonder a time when the world is fresh, and every event is impressive. The child during this period tries to acquire control over the environment. The child is born without fear and with a side-eyed interest around his environment. So the child should be provided an enriched environment for his sharp receptive mind to learn many things around him. Therefore, psychologists call this period as the period of plasticity as the impression that is made on the child's mind last throughout his life and influence his future career. Hence early childhood education should be made free, flexible and comprehensive in finding the best ways of getting families and schools to work together.

\section{Review of Related Studies}

Keeping the above facts in view, the present problemhas been selected for detail investigation. Chandrika (1989) reported 
that no sex difference was found in her study in Raven's colored progressive matrices and Weschler's Intelligence scale for children scores.

Prabhakar (1989) reported that the achievement of girls with pre-primary schools experience performed better both in English and Mathematics than the girls without pre-primary schools experience, whereas the difference is insignificant in case of boys with and without pre-primary schoolexperience. Muralidharan and Benerji (1974) reported that children having Pre-Primary school experience had done consistently better in all aspects of language development in Primary School than the children without primary school. Das \& Gary (1985) in their study reported that the children who had received Pre-primary classes before joining primary class achieved slightly higher in class -V than who did not receive Pre-Primary education. Whereas, Kasturi (1990) found that socio-economic status and Pre-Primary education have a positive impact on cognitive abilities. Age and Pre-School education have a significant effect on cognitive ability; also adolescent students performed significantly better than their Pre-adolescent counterparts, irrespective of their school experience. However, Mishra (1990) reported the reas on for the failure of Pre-School education. The half percentage of the teachersaid that there was a negative attitude at the organizational level towards Pre-Schools and staff.

\section{Rationale of the Study}

The rationale of the study gives focus on various aspects. There are some conflicting reports given by some earlier researchers related to the effectiveness of pre-primary education for better primary education. Some researchers reported that there is an insignificant difference between the achievement of primary schoolstudents with receiving and without receiving pre-primary school experience. Some also reported that primary school students do better achievements with pre-primary education than without pre-primary education. Hence, it is felt worthwhile to take this problem for further investigation.

So it is felt worthwhile to determine the difference in achievement between boys and girls of primary schools children with and without pre-primary school experience. Hence, the present study emerges out of above-cited reasons and factors. The researcher has selected this topic entitled "Pre-Primary Education: Its Impact on Academic Achievement of the Learners Learning at Elementary Stage in Odia Language Subject".

\section{Objectives of the Study}

The present study addressed the following objectives:

- To assess the achievement of learners learning at elementary schoollevel in Odia language subject both written and oral test with and without receiving pre-primary education.

- To compare the achievement of the boys and girls learning at elementary schoollevel in Odia language subject both written and oral test with and without receiving pre-primary education.

\section{Hypotheses of the Study}

The study also addressed with the following tentative solutions:

- H01. There exists no significant difference between the achievement of the boys learning at elementary school level in Odia language subject both written and oral test with and without receiving pre-primary education.

- H02. There exists no significant difference between the achievement of the girls learning at elementary school level in Odia language subject both written and oral test with and without receiving pre-primary education.

\section{Scope of the Study}

The scope of the study was as follows.

- Four Odia medium schools only.

- Learners of Class-I only.

- Achievement test on Odia language subject only.

- 15 boys and 15 girls from each school. 
- Urban schools only.

- Saraswati Sishu Mandirs at Nayagarh and Itamati only.

- College Lane Primary School, Nayagarh and New Town Primary School only

- Nayagarh District only.

- Nayagarh Block only.

\section{Methodology}

The investigator applied survey method in order to conduct this research work. The study aimed at finding a cause-effect relationship, the cause being the Pre-Primary education and the effect is the performance at Primary school stage. The investigator made the groups in this study such as the learners with and without Pre-Primary schooleducation.

\subsection{Sample}

The investigator adopted a combination of three sampling methods for the selection of students. First cluster method was followed by which four schools were selected randomly, two schools with Pre-Primary classes and the other two schools without Pre-Primary classes. Secondly, a stratified method was followed, i.e., 15 boys and 15 girls from each school were selected. Thirdly random sampling method was followed in which only 15 boys and 15 girls were selected from among the learners learning at the elementary level in class I. Out of four schools, two schools were attached with Pre-Primary classes and the other two schools were without it. The first groups of schools were Saraswati Sishu Mandir, Nayagarh and Saras wati Sishu Mandir, Itamati. The other group of schools was College Lane Primary School, Nayagarh and New Town Primary School, Itamati.

\subsection{Tools Used}

In this research study, the investigator used achievement test on Odia Language subject. The achievement test on Odia Language subject was used as a tool. The achievement test questionnaire was prepared on the syllabi for Class -I. This test measured the performance of the students with and without Pre-Primary education in Odia Language subject through oral and written test. Achievement test included the objectives such as knowledge, understanding and application ability. A blueprint of the achievement test was prepared which showed the weight to different objectives and types of test items.

\subsection{Statistical Techniques Used in the Study}

For the statistical study techniques such as mean, standard deviation and t-test were employed in order to compare the academic achievement in Odia language subject. Mean, Standard Deviation and t-test were employed for comparison between the learners with and without Pre-Primary school education. The difference between the learners with and without Pre-Primary education was tested for significance by t-test to know the significant difference between the learners with and without Pre-Primary education. Taking boys and girls separately, their mean, Standard Deviation was calculated for their performance in academic achievement for comparison.

\subsection{Procedure of Data Collection}

The performance of the learners learning in Class-I with and without receiving Pre-Primary education was tested by administering an achievement test over them. For this purpose, the achievement test was administered over the st udents of two schools with Pre-Primary education facility and other two schools without Pre-Primary education facility. In order to collect data, the investigator preceded all the schools, discussed with the Headmasters about the purpose of the present research study. With the permission of the Headmasters of the schools as well as the class teachers the investigator fixed the date of conducting the test and telling the students about the date and time of conducting the test in their respective schools. The questionnaire was administered over the students taking 15 boys and 15 girls of class -I as a sample. Both written and oral test was conducted overthe students.

\section{Data Analysis and Interpretation}

It is known in the table that the mean of the academic achievement of the learners with Pre-Primary School Education as well as without Pre-Primary School Education in Odia language subject in written test was 20.01 and 15.71 respectively and the mean difference is 4.30. This difference indicates that the Pre-Primary education is having significant contribution in Odia language subject of the learners learning at the elementary level in written test through various modes of teaching; as a result, the learners do better in academic achievement in Odia language subject. 
Rasmi Ranjan Puhan, Swagatika Ray, Sunakar Das

Pre-Primary Education: Its Impact on Academic Achievement of the Learners Learning at an Elementary Stage in Odia Language Subject in Odisha

Table 1: Achievement of the Learners with and Without Pre-Primary Education in Odia Language Written Test

\begin{tabular}{|c|c|c|c|c|c|c|}
\hline $\begin{array}{l}\text { Type of } \\
\text { Tests }\end{array}$ & Subjects & & $\begin{array}{l}\text { Vith Pre- } \\
\text { School }\end{array}$ & & $\begin{array}{r}\text { School } \\
\text { thout Pre- }\end{array}$ & $\begin{array}{l}\text { Mean } \\
\text { Difference }\end{array}$ \\
\hline \multirow[t]{2}{*}{ Written } & $\begin{array}{l}\text { Odia Language } \\
\text { Subject }\end{array}$ & $\mathrm{N}$ & Mean & $\mathrm{N}$ & Mean & \multirow[t]{2}{*}{4.30} \\
\hline & & 60 & 20.01 & 60 & 15.71 & \\
\hline
\end{tabular}

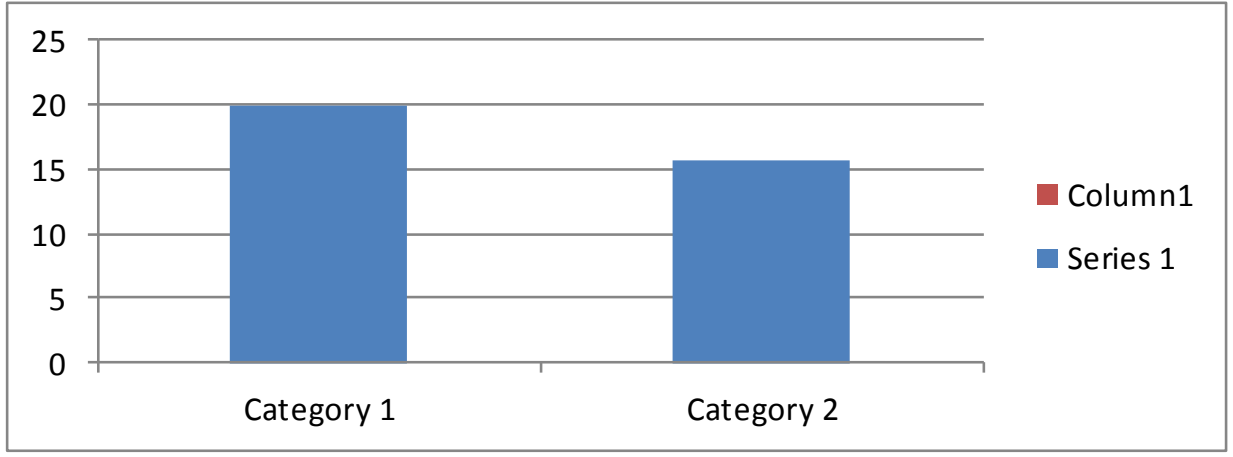

Figure 1

Table2: Achievement of the Learners With and Without Pre-Primary Education in Odia Language Oral Test

\begin{tabular}{|l|l|l|l|l|l|l|}
\hline $\begin{array}{l}\text { Type of } \\
\text { Tests }\end{array}$ & Subjects & $\begin{array}{l}\text { Learners With Pre- } \\
\text { Primary } \\
\text { Education }\end{array}$ & $\begin{array}{l}\text { Learners Without Pre- } \\
\text { School }\end{array}$ & $\begin{array}{l}\text { Mean } \\
\text { Primary School } \\
\text { Education }\end{array}$ & Difference \\
\hline Oral Test & $\begin{array}{l}\text { Odia Language } \\
\text { Subject }\end{array}$ & $\mathrm{N}$ & Mean & $\mathrm{N}$ & Mean & \multirow{2}{*}{3.08} \\
\cline { 3 - 6 } & 60 & 11.38 & 60 & 8.30 & \\
\hline
\end{tabular}

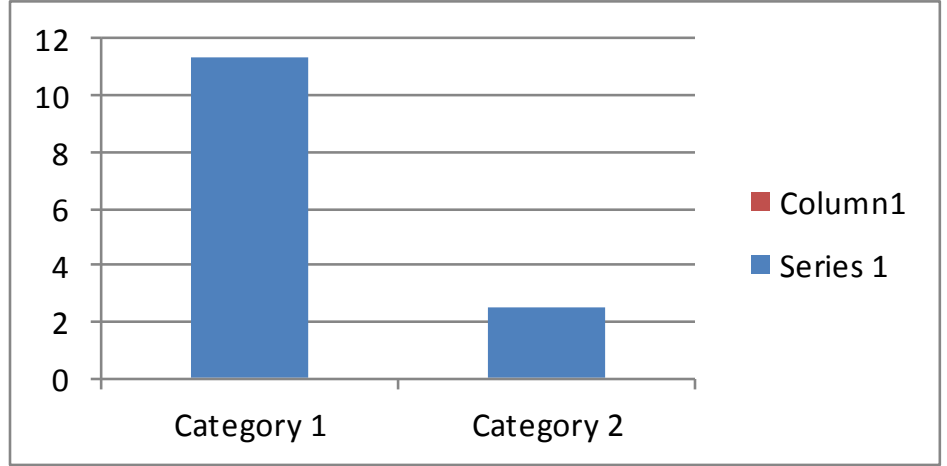

Figure 2

It is found in the table that the mean of the academic achievement of the learners with Pre-Primary School Education as well as without receiving Pre-Primary School Education in Odia language subject in the Oral test was 11.38 and 8.30 respectively and the mean difference is 3.08. This difference indicates that the Pre-Primary education is having significant contribution in Odia language subject of the learners learning at the elementary level in Oral test through various modes of teaching; as a result, the learners do better in academic achievement in Odia language subject. 
Rasmi Ranjan Puhan, Swagatika Ray, Sunakar Das

Pre-Primary Education: Its Impact on Academic Achievement of the Learners Learning at an Elementary Stage in Odia Language Subject in Odisha

Table 3: Comparis on of Achievement of the Boys With and Without Pre-Primary Education in Language Odia subject

\begin{tabular}{|l|l|l|l|l|l|l|l|l|}
\hline Type of Tests & Subjects & \multicolumn{3}{|l|}{$\begin{array}{l}\text { Boy s With Pre- } \\
\text { Primary Education }\end{array}$} & \multicolumn{2}{l|}{$\begin{array}{l}\text { Boys With Pre- } \\
\text { Primary Education }\end{array}$} & t-Value \\
\hline $\begin{array}{l}\text { Written and } \\
\text { Oral Test }\end{array}$ & $\begin{array}{l}\text { Odia Language } \\
\text { subject }\end{array}$ & $\mathrm{N}$ & Mean & S.D & N & Mean & S.D & \multirow{2}{*}{5.02} \\
\cline { 3 - 7 } & & 30 & 35.18 & 3.92 & 30 & 29.35 & 5.01 & \\
\hline
\end{tabular}

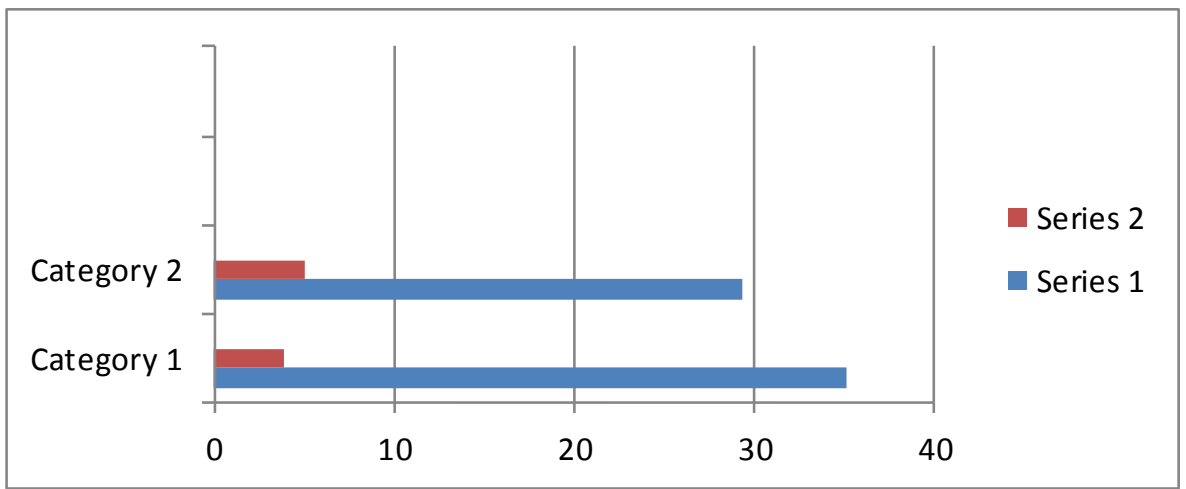

Figure 3

This table shows that ' $t$ ' value for achievement in Odia language subject of the boys with and without pre-primary education is 5.02 which is significant at both 0.01 and 0.05 levels with $\mathrm{df}=58$. This reflects that there exists a significant difference between achievement in Odia language subject of the boys with and without pre-primary school education. So, the null hypothesis- H01 "There exists no significant difference between the achievement of the boys learning at elementary school level in Odia language subject both written and oral test with and without pre-primary education" is rejected. As the mean of the boys attending pre-primary education in overall achievement is 35.18 and that of the boys without pre-primary education is 29.35 , it is inferred that boys with pre-primary education are significantly doing a better performance than the boys without attending pre-primary schooleducation.

Table 4: Comparis on of Achievement of the Girls With and Without Pre-Primary Education in Language Odia subject

\begin{tabular}{|l|l|l|l|l|l|l|l|l|}
\hline Type of Tests & Subjects & \multicolumn{2}{l|}{$\begin{array}{l}\text { Girls With Pre-Primary } \\
\text { Education }\end{array}$} & \multicolumn{2}{l|}{ Girls With Pre-Primary Education } & t-Value \\
\cline { 1 - 8 } Written and Oral & Language & $\mathrm{N}$ & Mean & S.D & $\mathrm{N}$ & Mean & S.D & \multirow{2}{*}{4.56} \\
\cline { 3 - 9 } & & 30 & 36.17 & 2.93 & 30 & 28.42 & 8.89 & \\
\hline
\end{tabular}

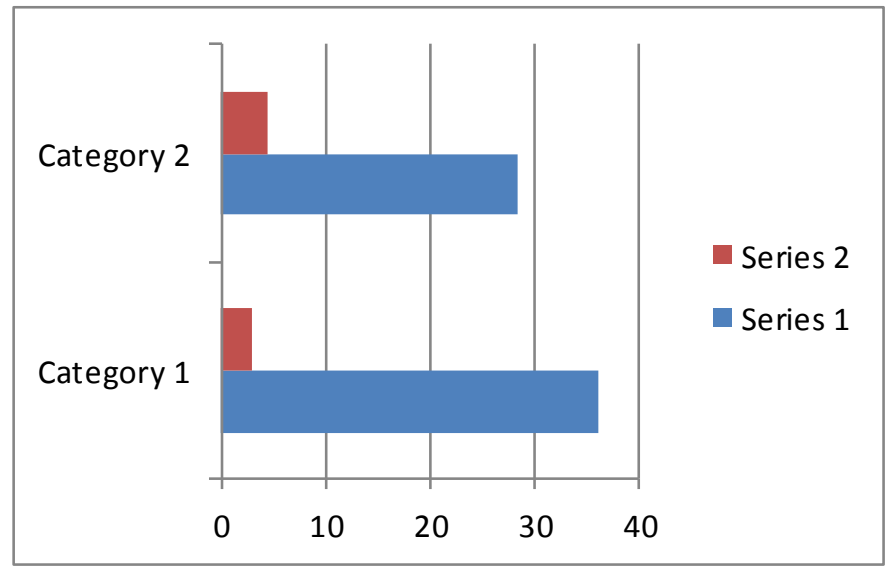


Figure 4

This table shows that ' $\mathrm{t}$ ' value for achievement in Odia language subject of the girls with and without pre-primary education is 4.56 which is significant at both 0.01 and 0.05 levels with $\mathrm{df}=58$. This reflects that there exists a significant difference between achievement in Odia language subject of the girls with and without pre-primary school education. So, the null hypothesis- H02 "There exists no significant difference between the achievement of the girls learning at elementary school level in Odia language subject both written and oral test with and without pre-primary education" is rejected. As the mean of girls attending pre-primary education in overall achievement is 36.17 and that of the girls without pre-primary education is 28.42 , it is inferred that the girls with pre-primary education are significantly doing a better performance than the girls without attending pre-primary schooleducation.

\section{Major Findings}

Following are the major findings of the present study:

- The mean of the academic achievement of the learners with receiving Pre-Primary School Education and without receiving Pre-Primary School Education in Odia language subject in written test was 20.01 and 15.71 respectively and the mean difference is 4.30. This difference indicates that the Pre-Primary education is having significant contribution in Odia language subject of the learners learning at the elementary level in written test through various modes of teaching; as a result, the learners do betterin academic achievement in Odia language subject.

- The mean of the academic achievement of the learners with receiving Pre-Primary School Education and without receiving Pre-Primary School Education in Odia language subject in the Oral test was 11.38 and 8.30 respectively and the mean difference is 3.08. This difference indicates that the Pre-Primary education is having significant contribution in Odia language subject of the learners learning at the elementary level in Oral test through various modes of teaching; as a result, the learners do betterin academic achievement in Odia language subject.

- The ' $t$ ' value for achievement in Odia language subject of the boys with and without pre-primary education is 5.02 which is significant at both 0.01 and 0.05 levels with $\mathrm{df}=58$. This reflects that there exists a significant difference between achievement in Odia language subject of the boys with and without pre-primary school education. So, the null hypothesis- H01 "There exists no significant difference between the achievement of the boys learning at elementary schoollevel in Odia language subject both written and oral test with and without pre-primary education" is rejected. As the mean of the boys attending pre-primary education in overall achievement is 35.18 and that of the boys without pre-primary education is 29.35 , it is inferred that boys with pre-primary education are significantly doing a better performance than the boys without attending pre-primary schooleducation.

- The ' $t$ ' value for achievement in Odia language subject of the girls with and without pre-primary education is 4.56 which is significant at both 0.01 and 0.05 levels with $\mathrm{df}=58$. This reflects that there exists a significant difference between achievement in Odia language subject of the girls with and without pre-primary school education. So, the null hypothesis- H02 "There exists no significant difference between the achievement of the girls learning at elementary schoollevel in Odia language subject both written and oral test with and without pre-primary education" is rejected. As the mean of girls attending pre-primary education in overall achievement is 36.17 and that of the girls without pre-primary education is 28.42 , it is inferred that the girls with pre-primary education are significantly doing a better performance than the girls without attending pre-primary schooleducation.

\section{Educational Implication}

It suggests that pre-primary education plays an acute role in the learning, social development, and health of primary school children while there are arguments against pre-primary education; no research supports not having pre-primary education. However, more research is needed to determine the current percentage of schools that have abolished the weight to pre-primary education and as sess the effort of no pre-primary education policies on student test scores, attitudes and behaviors. Further special care should be taken for different school subjects at the pre-primary level, for the cognitive development of the children.

As per LB. Sharp's dictum "Those things which can be taught in the outdoors should there be taught" (Quoted by Donaldson and Donaldson, 1958) has been accepted as a truis m by many nursery educators, and by extrapolation for all who promote outside the clas sroomlearning. Sharp, his as sociates, and their followers have provided numerous examples of situations wherein the environmental learning was, or could be more effective than about the environmental learning 
in the classroom. They also suggested that nursery or pre-primary education provides distinct educational advantages including cognitive ones, to other modes of instruction. Few of their pronouncements were supported by rigorous research; so sufficient weight should be given to pre-primary education for the promotion of cognitive, affective and psychomotor domains of these students.

\section{Educational Implication}

- The study may be taken for various grade levels, for different types of schools, for a different level of organizational instructors, for different content areas, for different schools subjects over a large sample to confirm the generalizability of the results and conclusions of the study.

- A study may be conducted on the feasibility in terms of the cultural milieu and teachers' acceptance.

- Effect of pre-primary education may also be studied in relation to individual differences and intelligence.

- Study on pupils' cognitive level, students ' background and conceptual level, environmental factors, creative potential can be taken in relation to pre-primary education.

- Studies can be undertaken on pre-primary education and its relation to the development of standard core components that need to be developed at an elementary stage, according to NPE-1986.

- From the findings, it is suggested that there may be pre-primary schools all over the States in India for all children within the age group +3 to +6 years irrespective of their caste, class, socio-economic status and sex, etc.

- The Government may extend provisions to pre-primary education centers in all parts of the State with necessary financial provision.

- Teacher training institutions may give training to the Pre-Primary schools'teachers for better pre-primary education for little children.

- Provisions may be made at the administrative level to improve the existing pre-primary schools in different States now in our country.

\section{Conclusion}

The investigator has taken care to assess the impact of the Pre-Primary Education on the academic performance of the learners learning at the elementary stage in Odia language subject. The findings of the study will help the learners, planners, policymakers, researchers, administrators to implement the results obtained from the problem for further researchers.

\section{References}

- Chandrika, D.C (1989) “The role of Anganwadi experience on the cognitive development of children”. In M. B. Bunch (Ed) Fifth Survey of Educational Research, New Delhi.

- Kasturi, Jachuck (1990) "Socio-economic status and time-related to the effect of pre-primary school education on cognitive abilities".

- Mishra. D (1990) A study of the problem of pre-school education in the city of Cuttack. In M.B. Buch (ED) Fifth survey of Educational Research, New Delhi.

- Muralidharan, R \& Banerjee, U (1974) "Effect of Pre-Primary school Education on Language and Intellectual Development of underprivileged children” In M.B. Buch (ED) second survey of Educational Research, NCERT, New Delhi.

- Prabhakar, Sunanda, P (1989) A study on the performance of elementary school children with and without nursery schoolexperience. In M.B. Buch (ED) Fifth survey of Educational Research, NCERT, New Delhi. 